Prof. Owhev during a recent visit to Brighton, called on the Mayor, Mr. Alderman Webb, and left a letter for his worship, on the desirability of taking steps for forming a collection or series of the Wealden Fossils of Sussex, corresponding, as far as time and means might permit, with the illustrations of the Chalk-beds which the Local Museum owes to the liberality of Mr. Willett. Not having been fortunate to meet with the Mayor, the Professor called on Mr. Cordy Burrowes, to whose active public spirit Brighton is much indebted. The worthy Alderman, who will probably hold the office of Mayor during the meeting of the British Association, entered warmly into the views of his visitor, and pledged bimself to promote their realization to the extent of his influence.

\title{
RIVER TERRACES, ETC.
}

Sm,-I certainly did not understand that Colonel Greenwood was speaking solely of terraces in closed valleys. This, it appears to me, was by no means clearly brought out in his first letter. With regard to these I can only say that, owing to the general correspondence between all these terraces that I have seen and those in the open valleys, it seems more natural to refer both to the same cause, viz., the action of water in motion upon detritus that has been mainly deposited in water comparatively at rest, and this, if your summary be correct, seems to be Professor Kjerulf's opinion. Doubtless a delta may be elevated by floods, but as a rule the amount thas gained would be small compared with the mass deposited under the permanent water level. I should regard the inland terraces to be remains of deltas, either deposited in fjords during a peried of depression, or in lakes which have been first more or less filled up, then re-excavated. In order to explain this, I do not think it necessary to burst any barriers, or call in other agencies to remove them than "rain and rivers" acting upon rocks liable to erosion. In thus venturing to differ from Colonel Greenwood, I would not be thought forgetful of the great services he has rendered to geologists by his careful observation of meteoric agents and their work in nature.

St. John's College, Camaraidge.

T. G. BONNEY.

\section{ERRATA IN THE PAPER, "ON THE SYSTEMATIC POSITION OF SIVATHERIUM GIGANTEUM."}

SrR,-In my communication on this subject in the October number of this Journal, I have observed two errors, which I feel it my duty to correct, in justice to the individuals concerned. At page 440, reference is made to Dr. Canfield's " concise paper on the manner of shedding and the nature of the Prongbuck's horns." This author has given some account of these, but to Mr. A. D. Bartlett, Superintendent of the Zoological Society's Gardens, the honour of the first accurate history is due (vide P.Z.S. 1865, p. 720). ${ }^{1}$ I might

1 This substitution of Dr. Canfield's name for that of Mr. Bartlett arose from Dr. Murie having accidentally quoted the wrong year of the Proceedings-namely, 1866, in which Dr. Canfield's (not Mr. Bartlett's) paper is published.-Edir. Groc. Mag. 